\section{STRUCTURE OF A PHOSPHORYLATED DERIVATIVE OF OLEANDOMYCIN, OBTAINED BY REACTION OF OLEANDOMYCIN WITH AN EXTRACT OF AN ERYTHROMYCIN-RESISTANT STRAIN OF ESCHERICHIA COLI}

Sir:

Strains of Enterobacteriaceae, highly resistant to erythromycin (EM), have been isolated in clinical settings, most often after therapy with EM. It has been reported that there exist two genes, ere $\mathrm{A}$ and ere $\mathrm{B}$, which encode an EM esterase and/or the erx (erm) gene which encodes an rRNA methylase ${ }^{1 \sim 7}$.

We investigated the inactivation of EM by EM-resistant strains clinically isolated in Japan. One of 197 strains of Escherichia coli, 3 of 77 strains of Klebsiella pneumoniae and 9 of 300 strains of Pseudomonas aeruginosa were selected from plates which contained $800 \mu \mathrm{g} / \mathrm{ml}$ of EM. The inactivation of EM by these 13 strains was investigated by the method of Kono et al. 8,8$)$ with intact cells and adenosine triphosphate (ATP). It was found that an EM-resistant strain $\left(\mathrm{MIC}^{10)}: 1,600 \mu \mathrm{g} / \mathrm{ml}\right)$ of $E$. coli, designated Tf481A, inactivated EM. A crude extract $\left(20 \mathrm{mg}\right.$ of protein $\left.{ }^{11} / \mathrm{ml}\right)$ of enzymes from the strain was prepared by the method of O'HARA et al. ${ }^{122}$. The extract also inactivated oleandomycin (OL), midekamycin and spiramycin. The inactivation was the result of an enzymatic reaction which was dependent on

Table 1. Requirements for inactivation of OL by a crude extract of enzymes from Escherichia coli Tf481A.

\begin{tabular}{cc}
\hline Reaction mixture & Inactivation $(\%)$ \\
\hline Complete system $^{\mathrm{a}}$ & 100 \\
- Crude enzyme extract & 0 \\
- ATP & 0 \\
$-\mathrm{Mg}\left(\mathrm{CH}_{3} \mathrm{COO}\right)_{2}$ & 0 \\
$-\mathrm{Mg}\left(\mathrm{CH}_{3} \mathrm{COO}\right)_{2}+\mathrm{MgCl}_{2}$ & 100 \\
$-\mathrm{KCl}$ & 100 \\
Control & 0 \\
\hline
\end{tabular}

a Crude extract dialyzed against TMK buffer (387.5 $\mu \mathrm{l}), 1 \mathrm{mg} / \mathrm{ml} \mathrm{OL}(12.5 \mu \mathrm{l})$ and $40 \mathrm{~mm}$ ATP $(100 \mu 1)$ were mixed and incubated together for 1 hour at $37^{\circ} \mathrm{C}$.

$b$ In the control, the crude extract was heated at $100^{\circ} \mathrm{C}$ for 3 minutes before use.
ATP and magnesium ions (Table 1).

OL was also a good substrate for the inactivation, and the structure of the inactivated form of OL was determined by physico-chemical techniques, which included UV absorption and IR spectrophotometry, ${ }^{31} \mathrm{P}$ and ${ }^{1} \mathrm{H}$ NMR and mass spectrometry. Preliminary reports of these data were presented ${ }^{13 \sim 15)}$.

E. coli $\mathrm{Tf} 481 \mathrm{~A}$ was grown in 4 liters of nutrient broth, with shaking at $37^{\circ} \mathrm{C}$, to the exponential phase. The cells were harvested by centrifugation, washed with TMK buffer $(0.06 \mathrm{M} \mathrm{KCl}$, $0.01 \mathrm{M}$ magnesium acetate and $0.006 \mathrm{M} 2$-mercaptoethanol in $0.1 \mathrm{M}$ Tris- $\mathrm{HCl}$ buffer, $\mathrm{pH} 7.8)^{12)}$ and suspended in $80 \mathrm{ml}$ of the same buffer. The cells in suspension were disrupted by sonication (Ohtake Sonicator, Tokyo) at $20 \mathrm{Kc}$ for 15 minutes and centrifuged at $22,000 \times g$ for 30 minutes at $4^{\circ} \mathrm{C}$ to remove cell debris. The supernatant thus obtained was used as a crude extract of enzymatic activity.

The reaction system for the inactivation of OL was as follows. $50 \mathrm{mg}$ of powdered $\mathrm{OL}$ (phosphate salt, Sigma, St Louis, U.S.A.) was mixed with $80 \mathrm{ml}$ of the crude extract and $20 \mathrm{ml}$ of $80 \mathrm{~mm}$ ATP (disodium salt) in TMK buffer, preneutralized to $\mathrm{pH} 7.8$ with $\mathrm{NaHCO}_{3}$. The complete reaction mixture was incubated overnight at $37^{\circ} \mathrm{C}$. The reaction was stopped by heating at $90^{\circ} \mathrm{C}$ for 3 minutes and the residual antibiotic activity in the reaction mixture was determined with Bacillus subtilis ATCC 663318). The reaction mixture containing the inactivated OL was centrifuged at $22,000 \times g$ for 30 minutes. The supernatant was extracted with $\mathrm{CHCl}_{3}$ to remove any remaining intact antibiotic and was then exhaustively extracted with $\mathrm{BuOH}$ to recover the inactivated $\mathrm{OL}$. The $\mathrm{BuOH}$ extract was evaporated to dryness under reduced pressure. The residue was dissolved in $2 \mathrm{ml}$ of $\mathrm{MeOH}-\mathrm{Me}_{2} \mathrm{CO}(1: 1)$. This solution of inactivated OL was passed over a column of silica gel $(2 \times 15 \mathrm{~cm})$. The chromatography was carried out with a $\mathrm{MeOH}-\mathrm{Me}_{2} \mathrm{CO}(1: 1)$ mixture as eluent, and $5 \mathrm{ml}$ fractions were collected. $5 \mu \mathrm{l}$ of each fraction were applied to a silica gel plate. Fractions containing the inactivated $\mathrm{OL}$ were detected by heating the silica gel plates after they had been sprayed with a $p$-anisaldehyde reagent (PAA), which consisted of $9 \mathrm{ml}$ of EtOH, $0.5 \mathrm{ml}$ of $p$-anisaldehyde and $0.5 \mathrm{ml}$ of sulfuric acid. The fractions which showed a violet color 
Table 2. Rf values of the inactivated OL by TLC.

\begin{tabular}{lccccc}
\hline \multirow{2}{*}{ Sample } & \multicolumn{3}{c}{ Rf in the indicated solvent system } & A & Antibiotic \\
\cline { 2 - 5 } activity $^{\mathrm{b}}$ & I & II & III & IV & \\
\hline Inactivated OL (Tf481A) & 0.18 & 0.07 & 0.40 & 0.34 & - \\
OL (W3110rif) & 0.34 & 0.34 & 0.16 & 0.34 & + \\
OL (TLC) & 0.34 & 0.34 & 0.16 & 0.34 & + \\
OL phosphate salt & 0.34 & 0.34 & 0.16 & 0.34 & + \\
\hline
\end{tabular}

\& Solvent systems were as follows: I, $\mathrm{MeOH}-\mathrm{Me}_{2} \mathrm{CO}(19: 6)$; II, $\mathrm{MeOH}-\mathrm{Me}_{2} \mathrm{CO}(1: 1)$; III, MeOH $\mathrm{H}_{2} \mathrm{O}(9: 1)$ and IV, $\mathrm{MeOH}$. TLC was performed on precoated Merck Silica gel plates (60 F 254). Location of compounds was detected by spraying with PAA and heating at $100^{\circ} \mathrm{C}$.

b Measured by bioautography.

Fig. 1. SI-MS of the inactivated $\mathrm{OL}$ and of $\mathrm{OL}$.

(A)

(A) Inactivated OL, (B) OL (W3110rif), (C) OL (TLC).

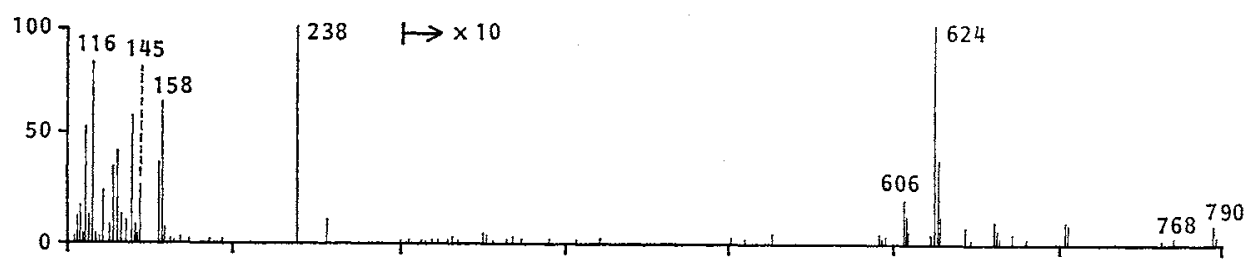

(B)

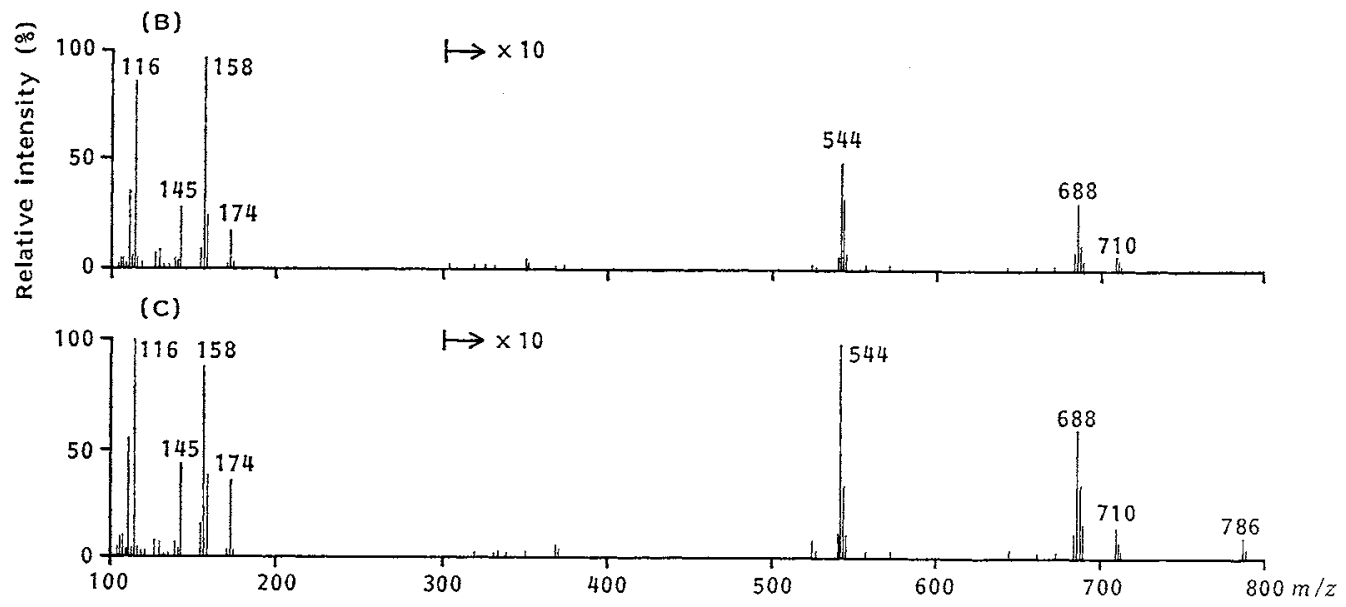

were positive for the PAA reaction and were evaporated to dryness under reduced pressure. The residue was dissolved in $\mathrm{MeOH}$. The crude preparation was spotted onto a silica gel plate. The inactivated OL was purified by TLC on the silica gel plate developed with $\mathrm{MeOH}$ $\mathrm{Me}_{2} \mathrm{CO}(19: 6)$, solvent $\mathrm{I}$ and with $\mathrm{MeOH}$ water $(9: 1)$. The inactivated $\mathrm{OL}$ was extracted from the silica gel plate with $\mathrm{MeOH}$. After filtration, the solution was dried, and the residue dissolved in distilled water and lyophilized, yielding $28 \mathrm{mg}$ of white powder.

On the other hand, OL purchased was also isolated by TLC on the silica gel plate as de- scribed above. And it was designated $\mathrm{OL}$ (TLC) and used as standard sample of OL.

Analysis by TLC of $\mathrm{OL}$ and inactivated $\mathrm{OL}$ yielded $\mathrm{Rf}$ values in solvent $\mathrm{I}$ of 0.34 and 0.18 , respectively. However, in $\mathrm{MeOH}$, the $\mathrm{Rf}$ values were identical for $\mathrm{OL}$ and inactivated $\mathrm{OL}$ and were equal to 0.34 (Table 2). A rifampicin resistant mutant of $E$. coli $\mathrm{K} 12 \mathrm{~W} 3110, E$. coli W3110rif ${ }^{17},{ }^{18}$, was used as internal control to check that $O L$ was not inactivated in a susceptible strain, and that the structure of inactivated $O L$ is not an artifact due to purification conditions. As a control, non-inactivated $\mathrm{OL}$, designated OL (W3110rif), was similarly extracted 
Fig. 2. ${ }^{1} \mathrm{H}$ NMR spectra of the inactivated OL and of OL.

(A) Inactivated OL, (B) OL (W3110rif), (C) OL (TLC).

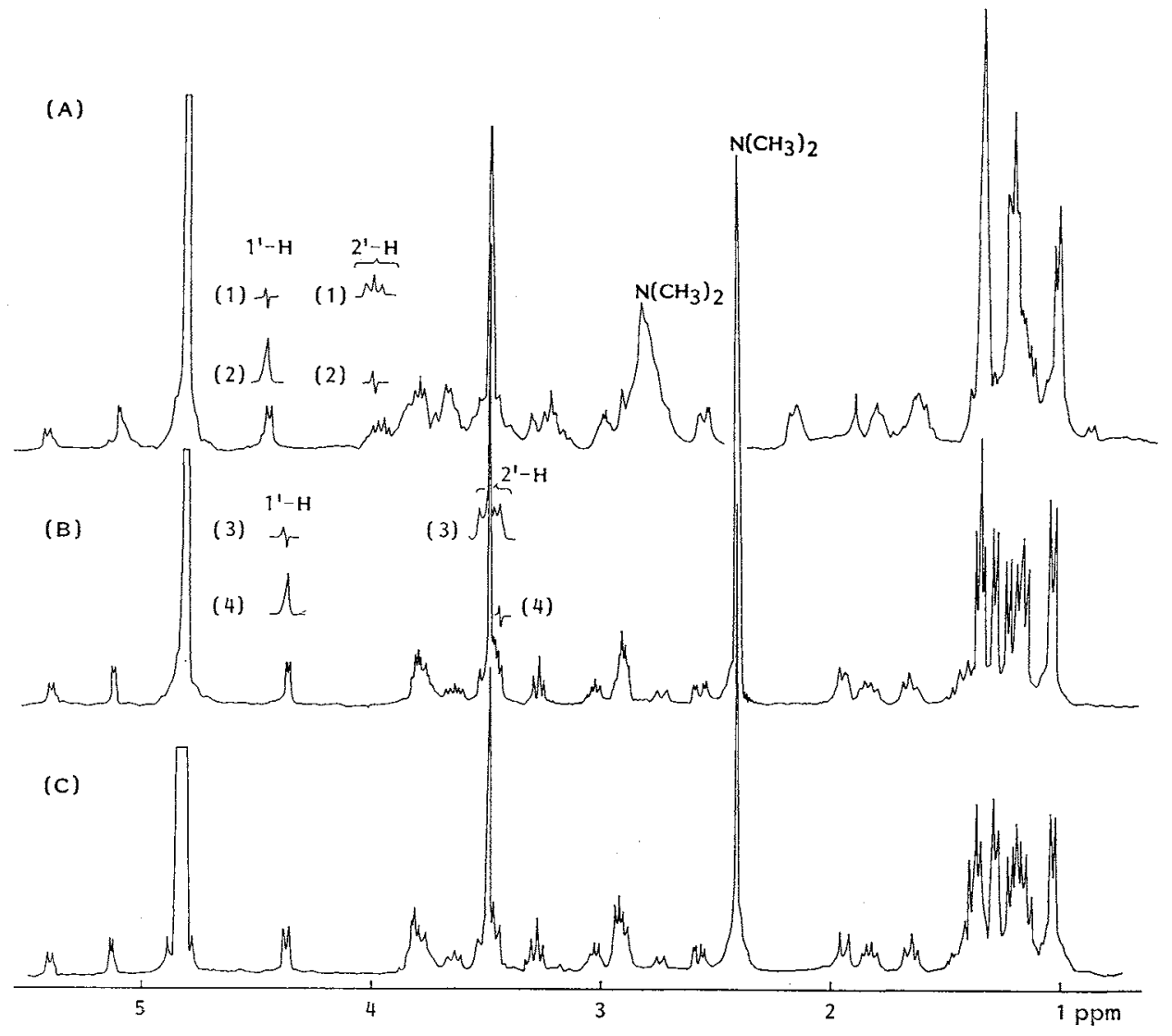

with $\mathrm{CHCl}_{3}$ after OL, ATP and a crude extract from the EM-susceptible (MIC: $100 \mu \mathrm{g} / \mathrm{ml}$ ) strain of E. coli W3110rif were incubated as described above, and was isolated by chromatography on silica gel plates under the same conditions. In each case, the chromatograms were developed by the ascending technique and visualized with either PAA or $50 \%$ sulfuric acid. The inactivated OL was seen as a single spot on TLC by each reagent and UV light. The spot of OL $(50 \mu \mathrm{g})$ on TLC plates showed antibiotic activity by bioautography and that of the inactivated OL did not (Table 2).

The UV spectra of OL and inactivated OL, dissolved in distilled water, were similar. The IR spectrum ( $\mathrm{KBr}$, Hitachi IR spectrophotometer 260-30 type) of the inactivated OL showed a phosphoric ester band at $965 \mathrm{~cm}^{-1}$. ${ }^{31} \mathrm{P}$ NMR spectra were obtained on a INM-FX200 spectrometer (Jeol) at $80.76 \mathrm{MHz}$ in deuterium oxide $\left(\mathrm{D}_{2} \mathrm{O}\right), \mathrm{pH}$ 7.0. The ${ }^{31} \mathrm{P}$ NMR spectrum of $\mathrm{OL}$ showed a peak for phosphate at $1.556 \mathrm{ppm}$ and the spectrum of the inactivated OL showed a peak for a phosphoric acid ester at $3.203 \mathrm{ppm}$.

The MS of the inactivated OL was compared to that of OL (Fig. 1). MS was obtained with a Hitachi M-80 Mass Spectrometer by secondary ion mass spectrometry (SI-MS). The MS of the phosphate salt of $\mathrm{OL}$ (MW 687 daltons) exhibited a $(\mathrm{M}+\mathrm{H})^{+}$ion at $m / z 688$ and $\left(\mathrm{M}+\mathrm{H}_{8} \mathrm{PO}_{4}+\mathrm{H}\right)^{+}$ ion at $m / z 786$.

As shown in Fig. 1B, OL (W3110rif) showed ionic peaks at $m / z 688$ and $710(\mathrm{M}+\mathrm{Na})^{+}$, and OL (TLC) exhibited ionic peaks at $m / z$ 688, 710 and 786 (Fig. 1C). However, the inactivated $\mathrm{OL}$ showed ionic peaks of $\left(\mathrm{M}(687)+\mathrm{HPO}_{3}(80)+\right.$ $\mathrm{H})^{+}$and $\left(\mathrm{M}+\mathrm{HPO}_{3}+\mathrm{Na}\right)^{+}$at $m / z 768$ and 790 , respectively (Fig. 1A). Therefore, the inactivated $\mathrm{OL}$ appeares to be a monophosphoryl OL (MW 767 daltons).

The ${ }^{1} \mathrm{H}$ NMR spectra were obtained with a Bruker AM-400 spectrometer at $400 \mathrm{MHz}$ in 
Fig. 3. Structure of the inactivated OL.

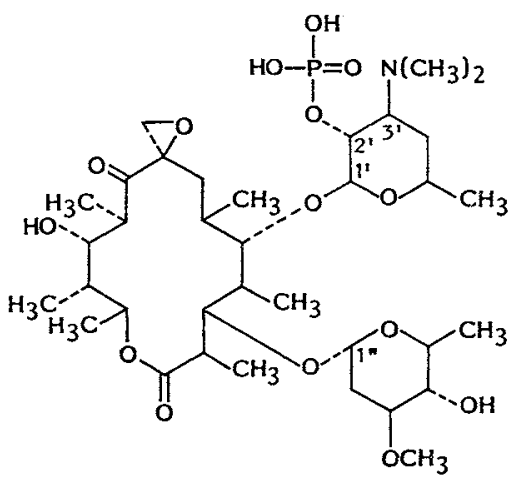

$\mathrm{D}_{2} \mathrm{O}$ solution, with 3-(trimethylsilyl)propionic acid- $d_{4}$ sodium salt (Merck) as internal reference $(0 \mathrm{ppm})$ (Fig. 2). It has been reported that the signals of the $\mathrm{C}-1^{\prime}$ and the $\mathrm{C}-1^{\prime \prime}$ anomeric protons in OL appear at about $4.26 \mathrm{ppm}$ and $5.01 \mathrm{ppm}$, respectively $\left.{ }^{13}, 20\right)$. The signals of the $\mathrm{C}-1^{\prime}$ proton in $\mathrm{OL}$ and the inactivated $\mathrm{OL}$ extracted from the silica gel plate were $4.32 \mathrm{ppm}$ (Figs. $2 \mathrm{~B}$ and $2 \mathrm{C}$ ) and $4.40 \mathrm{ppm}$ (Fig. 2A), respectively. The signals of the C-2' proton in OL and in the inactivated $\mathrm{OL}$ were determined by decoupling of each of the $\mathrm{C}-1^{\prime}$ proton signals as shown in Fig. 2 (1) (4). In the NMR spectrum of the inactivated $\mathrm{OL}$, the $\mathrm{C}-2^{\prime}$ proton signal at 3.44 ppm in OL was shifted to $3.93 \mathrm{ppm}$. The signal of the $\mathrm{C}-3^{\prime}-\mathrm{N}\left(\mathrm{CH}_{3}\right)_{2}$ protons at $2.40 \mathrm{ppm}$ (sharp singlet) in OL was shifted to $2.80 \mathrm{ppm}$ (broad signal) in inactivated OL. The broad signal in the inactivated OL changed to a sharp singlet upon heating of the inactivated OL at $80^{\circ} \mathrm{C}$. It is clear that phosphorylation must have occured at the $2^{\prime}-\mathrm{OH}$ of the desosamine moiety.

From the reported structure of $\mathrm{OL}^{21,22)}$, we have deduced the structure of the inactivated $\mathrm{OL}$ to be as shown in Fig. 3, namely the $2^{\prime}-O$ phosphoryl OL. Furthermore, the new macrolide(M)-inactivating enzyme from EM-resistant E. coli Tf481A can be identified as an M-2'phosphotransferase.

The inactivated compound formed by reaction of OL with an extract of EM-resistant $E$. coli Tf481A is the same as that generated by Streptomyces coelicolor and recently reported ${ }^{23)}$. Accordingly, it is interested in the properties of the M-2'-phosphorylating enzyme from EM-resistant E. coli $\mathrm{Tf} 481 \mathrm{~A}$.

\section{Acknowledgments}

We thank Dr. K. IGuchi, Mr. Y. SHIdA and Mrs. C. SAKumA, Department of Chemistry and Analytical Center, Tokyo College of Pharmacy, for spectral determinations (mass and NMR spectrometry). We thank Mr. T. Ikebuchi, Mr. K. YamakaWA and Miss M. HANE for technical assistance.

\section{KoJI O'HARA TOSHIHISA Kanda MEGUMI KONO*}

Department of Microbiology, Tokyo College of Pharmacy, 1432-1 Horinouchi, Hachioji, Tokyo 192-03, Japan

(Received February 8, 1988)

\section{References}

1) Barthélémy, P.; D. Autissier, G. Gerbaud \& P. Courvalin: Enzymic hydrolysis of erythromycin by a strain of Escherichia coli. A new mechanism of resistance. J. Antibiotics 37: $1692 \sim 1696,1984$

2) Ounissi, H. \& P. Courvalin: Nucleotide sequence of the gene ere $A$ encoding the erythromycin esterase in Escherichia coli. Gene 35: $271 \sim 278,1985$

3) Arthur, M.; A. Andremont \& P. Courvalin: Heterogeneity of genes conferring high-level resistance to erythromycin by inactivation in enterobacteria. Ann. Inst. Pasteur/Microbiol. $137 \mathrm{~A}: 125 \sim 134,1986$

4) Arthur, M.; D. Autissier \& P. Courvalin: Analysis of the nucleotide sequence of the ereB gene encoding the erythromycin esterase type II. Nucleic Acids Res. 14: 4987 4999, 1986

5) Andremont, A.; G. Gerbaud \& P. Courvalin: Plasmid-mediated high-level resistance to erythromycin in Escherichia coli. Antimicrob. Agents Chemother. 29: 515 518, 1986

6) Arthur, M. \& P. Courvalin: Contribution of two different mechanisms to erythromycin resistance in Escherichia coli. Antimicrob. Agents Chemother. 30: 694 700, 1986

7) Arthur, M.; A. Andremont \& P. Courvalin: Distribution of erythromycin esterase and rRNA methylase genes in members of the family Enterobacteriaceae highly resistant to erythromycin. Antimicrob. Agents Chemother. 31: 404 409, 1987

8) Kono, M.; K. O'Hara, K. Sato \& K. Ohmiya: Simple assay for determining streptomycin inactivation with intact cells of bacteria, and its applications to $P$. aeruginosa clinically isolated. 
Chemotherapy (Tokyo) 34: 281 285, 1986

9) Kono, M.; K. OhmiYa, T. Kanda, N. NoguCHI \& K. O'HARA: Purification and characterization of chromosomal streptomycin adenylyltransferase from derivatives of Bacillus subtilis Marburg 168. FEMS Microbiol. Lett. 40: $223 \sim 228,1987$

10) Japan Society of Chemotherapy. Method of MIC determination. Chemotherapy (Tokyo) 29: 76 79, 1981

11) Lowry, O. H.; N. J. Rosebrough, A. L. FARr \& R. J. RANDALL: Protein measurement with the Folin phenol reagent. J. Biol. Chem. 193: $265 \sim 275,1951$

12) O’Hara, K.; M. Kono \& S. Mitsuhashr: Structure of enzymatically acetylated sisomicin by Pseudomonas aeruginosa. J. Antibiotics 27: $349 \sim 351,1974$

13) KANDA, T.; K. O'HARA \& M. Kono: Macrolide resistance in Escherichia coli clinically isolated. Jpn. J. Bacteriol. (Japanese) 42: 361, 1987

14) Kanda, T.; K. O'HaRA \& M. Kono: Structure of inactivated oleandomycin by Escherichia coli Tf481A clinically isolated. Abstracts Papers of the 107th Annual Meeting of Pharmaceutical Society of Japan, No. 2Bb 1-5, p. 531, Kyoto, Apr. $2 \sim 4,1987$

15) O'hara, K.; T. Kanda, K. Ohmiya \& M. Kono: Properties of new macrolide-modifying enzyme from erythromycin-resistant Escherichia coli clinically isolated in Japan. Poster Abstracts of JUC Pharm. Sci. '87. The Japanese-United States Congress of Pharmaceutical Sciences. No. J 07-X-02, p. S190, Honolulu, Dec. $2 \sim 7,1987$

16) Kono, M.; H. Hamashima \& K. O'Hara:
Modification of aminoglycoside antibiotics by clinical isolates of Streptococcus faecalis. J. Antibiotics 34: 224 230, 1981

17) Kono, M.; K. O'Hara \& Y. Shromi: Nuclear magnetic resonance spectrometric assay of $\beta$ lactamase. Antimicrob. Agents Chemother. 17: $16 \sim 19,1980$

18) Kono, M.; K. O'Hara, K. Makino, H. HamaSHIMA \& M. SASATSU: R-Plasmid from a clinical isolate, Pseudomonas putida KPS45. In Current Chemotherapy and Immunotherapy. Proceedings of the 12th ICC., Vol. I. Eds., P. Peritr \& G. G. Grassi, pp. 208 210, The American Society for Microbiology, Washington, D. C., 1981

19) Celmer, W. D.: Macrolide stereochemistry. II. Configurational assignments at certain centers in various macrolide antibiotics. J. Am. Chem. Soc. $87: 1799 \sim 1801,1965$

20) Celmer, W. D. \& D. C. HobBs: The $\alpha$-L- and $\beta$-D-pyranoside linkages in oleandomycin. Carbohydr. Res. I: $137 \sim 144,1965$

21) Hochistein, F. A.; H. Els, W. D. Celmer, B. L. SHAPIRO \& R. B. WOODWARD: The structure of oleandomycin. J. Am. Chem. Soc. 82: 3225 3227,1960

22) Celmer, W. D.: Macrolide stereochemistry. I. The total absolute configuration of oleandomycin. J. Am. Chem. Soc. 87: 1797 1799, 1965

23) Wiley, P. F.; L. Baczynskyt, L. A. Dolak, J. I. Cialdella \& V.P. Marshall: Enzymatic phosphorylation of macrolide antibiotics. J. Antibiotics 40: 195 201, 1987 